\title{
HMs Induced Changes on Growth, Antioxidant Enzyme's Activity, gas Exchange Parameters and Protein Structures in Sasa Kongosanensis f. Aureo - Striatus
}

\author{
Abolghassem Emamverdian ${ }^{1,2}$, Yulong Ding ${ }^{1,3 *}$ \\ ${ }^{1}$ Co-Innovation Center for Sustainable Forestry in Southern China, Nanjing Forestry University, \\ Nanjing, 210037, China \\ ${ }^{2}$ College of Biology and the Environment, Nanjing Forestry University, \\ Nanjing, 210037, China \\ ${ }^{3}$ Bamboo Research Institute, Nanjing Forestry University, \\ Nanjing, 210037, China
}

Received: 22 June 2016

Accepted: 26 September 2016

\begin{abstract}
Nowadays, the contaminations generated by anthropogenic activities have had damaging effects on the life cycle of plants, particularly on the plants living in the vicinity of urban areas that are more associated with the life of people. Bamboo, as a local plant, is one of the most widely used plants in China. So, a pot experiment was conducted to investigate the effects of three $\mathrm{HMs}(\mathrm{Cu}, \mathrm{Pb}$, and $\mathrm{Zn})$ in four different concentrations ( 0 (for control), $500 \mathrm{mg} / \mathrm{kg}, 1000 \mathrm{mg} / \mathrm{kg}$, and $200 \mathrm{mg} / \mathrm{kg}$ ), with complete randomized design (CRD) by five replications for each treatment to measure the antioxidant enzymes, lipid per oxidation (LP), soluble protein (SP), gas exchange parameters, and morphological indexes in Sasa kongosanensis f. aureostriatus. The results indicated that the antioxidant responses had an arc-shaped trend with various alterations in which POD and CAT first increase with low concentration of HMs $(500 \mathrm{mg} / \mathrm{kg})$ and then decrease with the increase of heavy metal $(1000 \mathrm{mg} / \mathrm{kg}$ and $2000 \mathrm{mg} / \mathrm{kg})$. Additionally, measuring of MDA content and soluble protein illustrated that MDA content and soluble protein increase with excess of HMs in different levels, and also the excess of HMs significantly decreases the photosynthesis properties. Moreover, the results obtained by morphological indices showed that low concentration of HMs increases both percentage of shoot length and percentage of emerge plants at all three kinds of HMs, but observe a downward trend with excess of heavy metal in $1000 \mathrm{mg} / \mathrm{kg}$ and $2000 \mathrm{mg} / \mathrm{kg}$. Overall, in "Sasa kongosanensis f. aureo - striatus, results indicated that low concentration of HMs $(500 \mathrm{mg} / \mathrm{kg})$ can help the plant growth, while excess of HMs (1000-2000 mg/kg) alleviates the plant growth. On the other hand, $\mathrm{Pb}$ revealed the lowest antioxidant
\end{abstract}

*e-mail: ylding@vip.163.com 
activity that leads to most membrane damage and eventually showed the lowest plant growth among the cases that HMs were tested, while $\mathrm{Zn}$ showed the most increasing plant growth in low concentration.

Keywords: photosynthesis, plant growth, HMs, bamboo, enzyme's activity

\section{Introduction}

Today an excess of HMs produced by anthropogenic activities - including disposal of sewage sludge and industry, mining, agricultural operations, and atmosphere contamination - has reached the warning border for underground resources so that the leakage in underground sources and accumulation in agricultural soils has caused many ecological problems [1-2]. Recently, China's industrial development, besides numerous benefits, has created some superabundance environmental challenges such as the emergence of excessive HMs that could raise concerns about the mobility and availability of plants and, consequently, influence their growth and development [3]. There are two kinds of heavy metals in soil, namely essential and nonessential; essential HMs play an important role in many enzymes and other proteins and therefore, plants need them to grow and develop. HM concentration is counted as one important factor in the growth of plants so that excessive amounts of HMs can lead to a reduction in plant growth [4]. In plants, excess HMs cause a high dose of free radicals $\left(\mathrm{O}_{2 . \bullet}, \mathrm{OH} \bullet, \mathrm{OH}_{2}\right)$ and non-radical hydrogen peroxide $\left(\mathrm{H}_{2} \mathrm{O}_{2}\right)$, which eventually leads to the production of reactive oxygen species (ROS) [5-7]. ROS has a destructive reaction on the performance and efficiency of the cell membrane, including proteins, lipids, functions, permeability, and membrane-bound enzymes, and could lead to per oxidation of membrane lipids [5-8]. In fact, plants face some enzymes' mechanisms, including catalase (CAT, EC 1.11.1.6), per oxidases (POD, EC 1.11.1.7), and also a non-enzyme mechanism, including proline when they are exposed to extreme HMs [6-7, 9-10]. POD and CAT play an important role in $\mathrm{H}_{2} \mathrm{O}_{2}$-scavenging so that the $\mathrm{H}_{2} \mathrm{O}_{2}$ toxicity can be removed by dimensional reactions of CAT and POD [9-11] .The degradation of $\mathrm{H}_{2} \mathrm{O}_{2}$ to water and oxygen is carried out by catalase (CAT, EC 1.11.1.6) [5]. However, this may sever the stresses and restrain their enzymatic activity [11].

Bamboo, as a fast-growing plant, covers a wide area of forests in China [3]. Sasa kongosanensis f. aureo-striatus or Pleioblastus kongosanensis f.aureo - striatus, which is examined in our study, is an ornamental bamboo with clear green leaves and yellow stripes [12] that is known to be a natural antioxidant source [13]. The aims of our study is to investigate the decreasing rate of plant growth when exposed to an excess of HMs and illustrate the effect of bamboo on heavy metals.

\section{Materials and Methods}

A greenhouse experiment was conducted to determine toxicity of different concentrations of heavy metals (such as $\mathrm{Cu}, \mathrm{Pb}$, and $\mathrm{Zn}$ ) on the growth and development of one two-year-old ornamental bamboo species called Sasa kongosanensis $f$. aureo - striatus. Different heavy metal concentrations, including $0 \mathrm{mg} / \mathrm{kg}$ (control), $500 \mathrm{mg} / \mathrm{kg}$, $1,000 \mathrm{mg} / \mathrm{kg}$, and $2,000 \mathrm{mg} / \mathrm{kg}$, were considered for three heavy metals of $\mathrm{Cu}, \mathrm{Pb}$, and $\mathrm{Zn}$ that are common in the understudy areas. The experimental design was established under a completely randomized design of CRD with five replicates for each treatment. The R software package was used to analyze the variance of ANOVA using Tukey's test. Significance was determined at $\mathrm{p}<0.001 \quad(* \mathrm{p}<0.05$, $* * \mathrm{p}<0.01$, and $* * * \mathrm{p}<0.001)$. The tables are expressed as mean values and standard deviation (SD).

Plants were grown under excessive concentrations of heavy metals for a period of 60 days at control conditions. Specific amounts of heavy metals during the 60-day experimental period are summarized in Table 1. The concentrations of elements $(500 \mathrm{mg} / \mathrm{Kg}$, $1,000 \mathrm{mg} / \mathrm{Kg}$, and $2,000 \mathrm{mg} / \mathrm{Kg}$ ) were applied in the form of aqueous solution including $\left(\mathrm{Cu} \quad \mathrm{SO}_{4} \quad .5 \mathrm{H}_{2} \mathrm{O}\right)$ $\left(\mathrm{Pb}\left(\mathrm{NO}_{3}\right)_{2}\right)_{-}\left(\mathrm{Zn}\left(\mathrm{SO}_{4}\right) .7 \mathrm{H}_{2} \mathrm{O}\right)$. The weight of dry soil for pots was $0 / 710 \mathrm{~kg}=710 \mathrm{~g}$. After measuring the photosynthesis and morphological indexes, the samples were moved to the physiology laboratory of the Nanjing Forestry University for measuring the protein content and enzyme activity (free from pollution and sterilized).

The sampling leaves were squished in the oven so that all the interior organs were removed. For eliminating the interior tissues of the leaves, nitrogen liquid was used and then the resulting powder was mixed with $2 \mathrm{mg} \mathrm{pH} 7.8$ buffer in a test tube. Then samples were centrifuged at 7,000 rpm for 10 minutes. The estimation of antioxidant activities of peroxidase dismutase (POD, E.C. 1.11.1.7) was carried out according to [14]. The catalase CAT (EC 1.11.1.6) activity was evaluated based on [15]. LP of leaves was measured by estimating Malondialdehyde (MDA) content according to the method of [16] . The soluble protein was used to measure the changes in protein concentration in bamboo species as affected by heavy metal treatments. This protein estimation was done using Coomassie Brapt Blue G25, which is according to the procedure described by [17]. In this experiment gas exchange was measured by using a portable photosynthesis system (LI-6400, Li-Cor, Lincoln, NE, USA) equipped with light sources consisting

Table 1. Specific amounts of $\mathrm{HMs}(\mathrm{Cu}, \mathrm{Pb}$, and $\mathrm{Zn})$ in the experiment.

\begin{tabular}{|c|c|c|c|}
\hline HM concentrations & $\begin{array}{c}500 \\
\mathrm{mg} / \mathrm{kg}\end{array}$ & $\begin{array}{c}1,000 \\
\mathrm{mg} / \mathrm{kg}\end{array}$ & $\begin{array}{c}2,000 \\
\mathrm{mg} / \mathrm{kg}\end{array}$ \\
\hline $\begin{array}{c}\text { Amounts of HMs } \\
\text { in pot }\end{array}$ & $355 \mathrm{mg}$ & $710 \mathrm{mg}$ & $1,420 \mathrm{mg}$ \\
\hline
\end{tabular}


of blue-red light-emitting diodes (LI-6400-02B). The measurements were conducted at photosynthetic photon flux density (PPFD) of $1,000 \mu \mathrm{Mm}-2 \mathrm{~s}-1$, leaf temperature of $25^{\circ} \mathrm{C}$, and constant $\mathrm{CO}_{2}$ of $380 \pm 5 \mu \mathrm{M}$ $\left(\mathrm{CO}_{2}\right)$ mol-1 in the sample chamber provided with buffer volume. Morphological indexes included the length of the shoot and the number of emerged plants. To determine the percentage of shoot length, the heights of three to four of the tallest shoots in each pot were measured and their means were computed prior to the experiment. After the application of HM treatments, the mean heights of three to four of the tallest shoots in each pot along with the control ones were measured.

The percentage of shoot length (\%) was calculated as length of senesced shoots / length of emerged shoots $\times 100$. The emergence of new bamboo shoots occurred simultaneously during spring. Some of the emerged shoots withered away. So numbers of emerged shoots and senesced shoots were counted, and the percentage of senescent shoots (\%) was computed as numbers of senesced shoots / numbers of emerged shoots $\times 100$.

\section{Results and Discussion}

\section{Determining Antioxidant Activity}

Plants carry a defence mechanism to counter HM stresses, which increase antioxidant enzyme activities such as catalase (CAT, EC 1.11.1.6) or per oxidases (POD, EC 1.11.1.7) [18]. However, the reaction of plants to HMs is generally under the environmental influence of plant genotype [4]. The capacity of a plant antioxidant depends on the production and efficiency of antioxidant defence enzymes in the plant [19]. This means that sometimes the level of antioxidant in the cell membrane is not enough and can reduce the amount of ROS [20]. Our results, compared with control treatment, indicate that the HM concentrations significantly increased the antioxidant enzymes activities (POD and CAT) in Sasa kongosanensis (Table 2) to $37 \%, 31 \%$, and $46 \%$ in POD activity, and $106 \%, 79 \%$, and $127 \%$ in CAT activity by $\mathrm{Cu}, \mathrm{Pb}$, and $\mathrm{Zn}$, respectively.

Among the reasons for the increase of antioxidant activity in our species, the plant's natural response can be pointed out when it is confronted with heavy-metal stress. This issue has been reported in several studies such as: 1) POD and CAT activities under Cd stress at tomato seedlings [21]; 2) SOD, POD, and CAT activities under $\mathrm{Cu}$ stress at Astragalus neo-mobayenii [10]; and 3) SOD and POD activities at Typha angustifolia under $\mathrm{Cr}, \mathrm{Pb}$, and Cd stress [22].

However, the results revealed that the antioxidant activities first increase with low concentrations of heavy $\mathrm{metal}(500 \mathrm{mg} / \mathrm{kg})$ and then decrease with an excess of HMs at concentrations of 1,000 and $2,000 \mathrm{mg} / \mathrm{kg}$, respectively (Table 2). This increase in antioxidants can be either the plant effort to survive with the accumulation of HMs, or the threshold defence mechanism of plants to avoid oxidative stress with the accumulation of HMs. Therefore, when this phenomenon occurs, that amount of the ROS is more than the capacity of the plant antioxidant enzymes [23]. The excessive amount of superoxide radical could lead to an interaction between the cell compound and the HMs so that it impairs the transmission of signals to the gene used for antioxidants. This interdiction can occur by replacing

Table 2. The effects of $\mathrm{HMs}(\mathrm{Cu}, \mathrm{Pb}$, and $\mathrm{Zn})$ on the POD, CAT, MDA, and soluble protein of sasa kongosanensis f. aureo - striatus. Each data point is a mean value $\pm \mathrm{SE}$ of five replicates. The capital letters are the demonstration of statistical significance between different concentrations of HMs and the small letters are the demonstration of statistical significance between different HMs in each concentration.

\begin{tabular}{|c|c|c|c|c|c|}
\hline \multirow{3}{*}{ Heavy metal } & Treatment & POD & CAT & MDA & SP \\
\cline { 2 - 6 } & $\mathrm{mg} / \mathrm{kg}$ & u.g.FW & u.g.FW & $\mu$ mol.g.Fw & $\mathrm{mg} / \mathrm{g} . \mathrm{FW}$ \\
\hline \multirow{3}{*}{$\mathrm{Cu}$} & 0 & $0.75 \pm 0.10^{\mathrm{Ba}}$ & $0.023 \pm 0.004^{\mathrm{Ca}}$ & $0.041 \pm 8.10^{\mathrm{Aa}}$ & $0.029 \pm 0.011^{\mathrm{Bb}}$ \\
\cline { 2 - 6 } & 500 & $1.13 \pm 0.18^{\mathrm{Aa}}$ & $0.054 \pm 0.004^{\mathrm{Aa}}$ & $0.044 \pm 6.42^{\mathrm{Aa}}$ & $0.033 \pm 0.008^{\mathrm{Bb}}$ \\
\cline { 2 - 6 } & 1,000 & $1.02 \pm 0.16^{\mathrm{Aa}}$ & $0.047 \pm 0.006^{\mathrm{ABa}}$ & $0.046 \pm 9.76^{\mathrm{Aa}}$ & $0.052 \pm 0.007^{\mathrm{Ab}}$ \\
\hline \multirow{3}{*}{$\mathrm{Pb}$} & 2,000 & $0.94 \pm 0.08^{\mathrm{ABa}}$ & $0.040 \pm 0.006^{\mathrm{Ba}}$ & $0.059 \pm 3.87^{\mathrm{Ab}}$ & $0.062 \pm 0.007^{\mathrm{Ab}}$ \\
\cline { 2 - 6 } & 0 & $0.74 \pm 0.18^{\mathrm{Ba}}$ & $0.029 \pm 0.005^{\mathrm{Ca}}$ & $0.039 \pm 0.013^{\mathrm{Ca}}$ & $0.042 \pm 0.005^{\mathrm{Ca}}$ \\
\cline { 2 - 6 } & 500 & $1.13 \pm 0.19^{\mathrm{Aa}}$ & $0.061 \pm 0.007^{\mathrm{Aa}}$ & $0.067 \pm 0.015^{\mathrm{Ba}}$ & $0.045 \pm 0.008^{\mathrm{Cab}}$ \\
\cline { 2 - 6 } & 1,000 & $0.95 \pm 0.14^{\mathrm{ABa}}$ & $0.053 \pm 0.008^{\mathrm{ABa}}$ & $0.085 \pm 0.013^{\mathrm{ABa}}$ & $0.087 \pm 0.005^{\mathrm{Ba}}$ \\
\hline \multirow{3}{*}{$\mathrm{Zn}$} & 2,000 & $0.87 \pm 0.23^{\mathrm{ABa}}$ & $0.044 \pm 0.009^{\mathrm{Ba}}$ & $0.093 \pm 0.014^{\mathrm{Aa}}$ & $0.107 \pm 0.009^{\mathrm{Aa}}$ \\
\cline { 2 - 6 } & 0 & $0.63 \pm 0.13^{\mathrm{Ba}}$ & $0.020 \pm 0.005^{\mathrm{Ba}}$ & $0.043 \pm 0.017^{\mathrm{Aa}}$ & $0.041 \pm 0.003^{\mathrm{Cab}}$ \\
\cline { 2 - 6 } & 500 & $0.98 \pm 0.22^{\mathrm{Aa}}$ & $0.058 \pm 0.007^{\mathrm{Aa}}$ & $0.049 \pm 0.012^{\mathrm{Aa}}$ & $0.053 \pm 0.005^{\mathrm{BCa}}$ \\
\cline { 2 - 6 } & 1,000 & $0.91 \pm 0.11^{\mathrm{ABa}}$ & $0.049 \pm 0.001^{\mathrm{Aa}}$ & $0.051 \pm 0.011^{\mathrm{Aa}}$ & $0.065 \pm 0.014^{\mathrm{ABb}}$ \\
\cline { 2 - 6 } & 2,000 & $0.89 \pm 0.23^{\mathrm{ABa}}$ & $0.032 \pm 0.008^{\mathrm{Ba}}$ & $0.051 \pm 0.016^{\mathrm{Ab}}$ & $0.074 \pm 0.013^{\mathrm{Ab}}$ \\
\hline
\end{tabular}


and blocking the ions in important groups of cells [24]. This phenomenon has been confirmed and emphasized by many researchers in various plants such as: 1) SOD, POD, and CAT activities under $\mathrm{Cr}$ stress in mung beans [25]; 2) antioxidant enzyme activity of Suaeda heteroptera under $\mathrm{Cu}$ stress [26]; 3) SOD and CAT activity under lead stress in water hyacinths Eichhornia crassipes (Mart.) [27]; and 4) CAT activity under $\mathrm{Pb}$ stress in Sesbania grandiflora [28].

Overall, the present study's antioxidant enzymatic activities have shown an arc-shaped response to different levels of HMs in which antioxidant enzymes first increased at low concentrations of HM and then decreased with an excess of heavy metal. Hence, compared with control treatment, the increased amount at different concentrations of $\mathrm{HMs}$ in $\mathrm{POD}$ and CAT activities are $\mathrm{Zn}>\mathrm{Cu}>\mathrm{Pb}$ (Table 2).

\section{Determination of Lipid per Oxidation (LP) and Soluble Protein (SP)}

Basically, the LP could be used as an indicator of oxidative stress on the plants $[9,29-30]$. When the antioxidant enzyme is unable to wipe out the damaging effects of free radicals and ROS in plants completely, the LP causes the oxidation of membrane lipids that can disable the cell structure and membrane of the organelle [9]. The level of the damage is characterized by measuring the MDA content, because increasing MDA controls the oxidative stress rate in plants [31-11]. According to our results, the MDA content significantly increases with increasing HMs compared with control treatments: $22 \%$, $110 \%$, and $15 \%$ for copper, lead, and zinc, respectively (Table 2). One of the reasons that this increase can show a lack of enough efficiency of antioxidant enzymes is that due to the increase of ROS amount, the free radicals in the cell membranes will increase, consequently leading to the destruction of cell membranes and increasing the lipid per oxidation in cell membranes of bamboo species. The amount of increase is related to the sensitivity of species to cell damage by ROS [32]. Moreover, the excess of heavy metals could lead to an excess of lipid per oxidation, which may in turn lead to the disruption of either membrane permeability and efficiency or enzyme activities such as H+-ATPase [33]. The effects of copper on S. alterniflora showed that the excess of $\mathrm{Cu}$ with ameliorate membrane permeability lead to the production of superoxide radicals and oxidative stress in plants, and then lead to the enhancement of lipid per oxidation in cell membrane [34]. This issue has been confirmed in several studies concerning the: 1) effect of lead and $\mathrm{Cd}$ in mung bean [35], 2) lead on sedum [36], 3) $\mathrm{Cd}$ on in Linum usitatissimum L [37], and 4) copper on duckweed, cucumber, and Silene paradoxa L [8, 38-39].

Furthermore, in another study [29] indicated that in excess of $\mathrm{Cu}$, there is one direct link between the excess of heavy metal and overproduction of reactive oxygen species (ROS) with an excess of cellular permeability.
This link can result in the production of lipid per oxidation in cell membrane, and it can be an impairment in connection and correlation between lipids and proteins in cell membrane. Moreover, ROS with oxidation in protein structure at cell membrane leads to impairment in the amino acid chain and overproduction carbonyl groups [40]. The present work tries to provide strong evidence to show that with an excess of heavy metal, soluble protein content would significantly increase. That amount of the increase is seen to be $68 \%, 86 \%$, and $57 \%$ by copper, lead, and zinc compared with the control treatment (Table 2). It then revealed that damaging effects of HMs lead to the fragmentation of proteins in cell membrane [41].

\section{Gas Exchange Parameters (Photosynthesis Indices)}

The proper amount of essential $\mathrm{HMs}$, like $\mathrm{Cu}, \mathrm{Zn}$, $\mathrm{Co}$, and $\mathrm{Fe}$, are useful for plant metabolism; however, extreme values of HMs disturb some photosynthesis and metabolism activities in plants. HMs can impact plants directly and indirectly. For example, they indirectly decrease net photosynthesis and transpiration in plants by causing a disturbance in the stomatal structure [42]. HMs directly disturb the structure of thylakoid membranes at chloroplast and photosynthetic proteins, which mainly damage the efficiency photochemistry parameters in the dark-adapted state (fv/fn) and PSII [43], and reduce energy transfers to the reaction centre [44].

Gas exchange parameters in Sasa kongosanensis $f$. aureo-striatus indicated that concentrations of HMs had a negative effect on photosynthesis parameters so that at high concentrations $(1,000-2,000 \mathrm{mg} / \mathrm{kg})$ it leads to a significant decrease in the net photosynthetic rate (PN), conductance to $\mathrm{H}_{2} \mathrm{O}$ (Cond), intercellular $\mathrm{CO}_{2}$ concentration $(\mathrm{Ci})$, and transpiration rate $(\mathrm{Tr})$. As indicated in Table 3, all the photosynthetic properties were reduced by rising HM concentrations compared to those within their control. Many researchers have pointed to HMs as an inhibitor in the net photosynthetic rate and other photosynthesis properties [45-46]. The results of one experiment revealed that the impacts of two $\mathrm{HMs}(\mathrm{Cr}$ and $\mathrm{Ag})$ on Cyanobacterium, Spirulina platensis downgraded $17 \%$ of the whole chain electron transport activity (WCE), and also indicated that $15 \mu \mathrm{M}$ of $\mathrm{Ag}$ and $100 \mu \mathrm{M}$ of $\mathrm{Cr}$ decreased electron transport and PS2 activities by $55-66 \%$ and 61-62\%, respectively. Thus, a high concentration of $\mathrm{HMs}$, such as $\mathrm{Cr}$ and $\mathrm{Ag}$, with inhibitory effects on light and energy absorption, make a disturbance in the reaction centre and light harvesting complex (LHc), which consequently leads to a disturbance of chain electron transport and transfer systems at Ps II [47]. In another study, a similar impact has been observed in chloroplasts, BBYs, Thylakoid membranes, and PSII complexes [48]. Generally, HMs lead to the inhibition of net photosynthetic rate (Pn) and intracellular $\mathrm{CO}_{2}$ concentration [45]. Bazihizina et al. (2015) [38] have shown that "stomatal closure attribution" is the most important reason for reducing photosynthesis in plants that are exposed to copper. 
Table 3. The effects of $\mathrm{HMs}(\mathrm{Cu}, \mathrm{Pb}$, and $\mathrm{Zn})$ on gas exchange parameters (photosynthesis indices) of sasa kongosanensis $f$. aureo striatus. Each data point is mean value $\pm \mathrm{SE}$ of five replicates. The capital letters are the demonstration of statistical significance between different concentrations of HMs and the small letters are the demonstration of statistical significance between different HMs in each concentration.

\begin{tabular}{|c|c|c|c|c|c|}
\hline \multirow[t]{2}{*}{ Heavy metal } & Treatment & $\begin{array}{l}\text { Net photosynthetic rate } \\
\qquad(\mathrm{Pn})\end{array}$ & $\begin{array}{l}\text { Conductance to } \mathrm{H}_{2} \mathrm{O} \\
\text { (Cond) }\end{array}$ & $\begin{array}{l}\text { Intercellular } \mathrm{CO}_{2} \\
\text { concentration } \\
\text { (CI) }\end{array}$ & $\begin{array}{l}\text { Transpiration rate } \\
\text { (Trimmol) }\end{array}$ \\
\hline & $\mathrm{mg} / \mathrm{kg}$ & $\mu \mathrm{mol} \mathrm{CO} \mathrm{Cm}^{-21}$ & $\mathrm{~mol} \mathrm{H}_{2} \mathrm{O} \mathrm{m}^{-2} \mathrm{~s}^{-1}$ & $\mu \mathrm{mol} \mathrm{CO} \mathrm{mol}^{-1}$ & $\mathrm{mmol} \mathrm{H}_{2} \mathrm{Om}^{-2} \mathrm{~s}^{1}$ \\
\hline \multirow{4}{*}{$\mathrm{Cu}$} & 0 & $64.16 \pm 1.30^{\mathrm{Aa}}$ & $0.10 \pm 0.04^{\mathrm{Aa}}$ & $26.93 \pm 8.10^{\mathrm{Aa}}$ & $1.7 \pm 0.3^{\mathrm{Aa}}$ \\
\hline & 500 & $60.22 \pm 2.22^{\mathrm{Aa}}$ & $0.09 \pm 0.02^{\mathrm{Aa}}$ & $23.68 \pm 6.42^{\mathrm{Aa}}$ & $1.5 \pm 0.5^{\mathrm{Aa}}$ \\
\hline & 1,000 & $55.24 \pm 2.72^{\mathrm{Ba}}$ & $0.08 \pm 0.03^{\mathrm{ABa}}$ & $16.99 \pm 9.76^{\mathrm{Aa}}$ & $1.4 \pm 0.3^{\mathrm{Aa}}$ \\
\hline & 2,000 & $49.71 \pm 2.52^{\mathrm{Ca}}$ & $0.04 \pm 0.01^{\mathrm{Ba}}$ & $13.84 \pm 3.87^{\mathrm{Aa}}$ & $1.3 \pm 0.2^{\mathrm{Aa}}$ \\
\hline \multirow{4}{*}{$\mathrm{Pb}$} & 0 & $64.63 \pm 2.13^{\text {Аa }}$ & $0.15 \pm 0.02^{\mathrm{Aa}}$ & $25.20 \pm 7.44^{\mathrm{Aa}}$ & $2.3 \pm 0.33^{\mathrm{Aa}}$ \\
\hline & 500 & $58.25 \pm 3.58^{\mathrm{Ba}}$ & $0.10 \pm 0.03^{\mathrm{ABa}}$ & $22.05 \pm 3.98^{\mathrm{Aa}}$ & $2.2 \pm 0.34^{\mathrm{Aa}}$ \\
\hline & 1,000 & $51.27 \pm 3.15^{\mathrm{Ca}}$ & $0.09 \pm 0.04^{\mathrm{ABa}}$ & $20.83 \pm 4.18^{\mathrm{ABa}}$ & $1.9 \pm 0.36^{\mathrm{ABa}}$ \\
\hline & 2,000 & $41.07 \pm 1.87^{\mathrm{Da}}$ & $0.06 \pm 0.02^{\mathrm{Ba}}$ & $18.03 \pm 7.13^{\mathrm{Aa}}$ & $1.8 \pm 0.53^{\mathrm{Aa}}$ \\
\hline \multirow{4}{*}{$\mathrm{Zn}$} & 0 & $64.26 \pm 1.38^{\mathrm{Aa}}$ & $0.19 \pm 0.03^{\mathrm{Aa}}$ & $17.48 \pm 5.45^{\mathrm{Aa}}$ & $2.1 \pm 0.46^{\mathrm{Aa}}$ \\
\hline & 500 & $62.07 \pm 1.92^{\mathrm{ABa}}$ & $0.16 \pm 0.10^{\mathrm{Aa}}$ & $16.48 \pm 5.18^{\mathrm{Aa}}$ & $1.9 \pm 0.23^{\mathrm{ABa}}$ \\
\hline & 1,000 & $59.50 \pm 1.55^{\mathrm{Ba}}$ & $0.14 \pm 0.06^{\mathrm{Aa}}$ & $15.57 \pm 5.95^{\mathrm{Aa}}$ & $1.6 \pm 0.35^{\mathrm{ABa}}$ \\
\hline & 2,000 & $54.64 \pm 3.04^{\mathrm{Ca}}$ & $0.13 \pm 0.04^{\mathrm{Aa}}$ & $15.23 \pm 3.70^{\mathrm{Aa}}$ & $1.4 \pm 0.29^{\mathrm{Ba}}$ \\
\hline
\end{tabular}

A previous study showed the effects of $\mathrm{HMs}(\mathrm{Cu}$ and $\mathrm{Pb})$ on $\mathrm{B}$. napus and implicated the excessive amount of $\mathrm{Cu}(50$ or $100 \mathrm{Mm})$ in the decline of a number of photosynthetic-related indices, including the rate of photosynthesis ( $\mu \mathrm{mol} \mathrm{CO}$ m-2 s-1), intercellular $\mathrm{CO}_{2}$ concentration ( $\mu \mathrm{mol} \mathrm{CO}_{2}$ mol-1), conductance to $\mathrm{H}_{2} \mathrm{O}$ (mol $\mathrm{H}_{2} \mathrm{O} \mathrm{m}-2 \mathrm{~s}-1$ ), and net assimilation, as well as transpiration [30]. It also significantly decreased the transpiration rate, stomatal conductance, net photo synthetic rate, and water use efficiency by $\mathrm{Pb}[49]$. Overall, in the present study photosynthetic properties in three $\mathrm{HMs}$ of $\mathrm{Cu}, \mathrm{Pb}$, and $\mathrm{Zn}$ significantly decreased by approximately 1.18-, 1.29- and 1.14-fold of the control, respectively (Table 3 ).

\section{Determining Plant Growth (Percentage of Shoot Length and Percentage of Emerge Plants)}

One important point in the growth of plants exposed to abiotic stress, such as HM stress, is the ability of plant antioxidant enzyme activities in confronting oxidative stress [50]. The results of analysis on the effects of HMs $(\mathrm{Cu}, \mathrm{Pb}, \mathrm{Zn})$ on the percentage of shoot length and percentage of emerge plants in Sasa kongosanensis $f$ showed that, compared with control treatments, the percentage of plant growth mainly increased with low concentrations $(500 \mathrm{mg} / \mathrm{kg})$ of $\mathrm{HMs}(\mathrm{Cu}, \mathrm{Pb}$, and $\mathrm{Zn})$, and then significantly decreased with an excess of HMs $(1,000$ and $2,000 \mathrm{mg} / \mathrm{kg}$ ) (Fig. 1). This reduction was demonstrated in copper, lead, and $\mathrm{Zn}$ by $21 \%, 27 \%$, and $10 \%$ of shoot length (Fig. 1a) and $13 \%, 23 \%$, and $6 \%$ of emerged plants (Fig. 1b). A reduction of growth in high concentrations has been reported by lead at Sesbania grandiflora and Chinese cabbage cultivars [28-51] by $\mathrm{Cu}$ at halophyte Spartina (poace) and Brassicanapus L. and Lemna minor L. [2, 52-53], and by $\mathrm{Zn}$ in sugarcane and bean [53-54]. Many factors are involved in inhibiting plant growth when they are exposed to high concentrations of HMs. Zaheer [30] indicated that the effects of copper on the growth rate of B. napus significantly decreased with the excess of $\mathrm{Cu}$, in which this decline is attributed to changes in root morphology and impairment of nutrient uptake. Another study by Ali [55] shows that this decrease in wheat plant growth rates is attributed to the mesophilic cell dysfunction because of oxidative stress in leaves. Later, in other studies, it was mentioned that the reason for this matter is decreasing photosynthesis and chlorophyll and increasing MDA [1956]. The other point that was clearly observed in our study as well is that the excess of heavy metal and inhibition of plant growth can lead to chlorosis, necrosis, and leaf depigmentation [2].

On the other hand, the results indicated that the percentage of plant growth, compared with control treatment, has mainly shown a positive reaction at low concentrations $(500 \mathrm{mg} / \mathrm{kg}$ ) that could lead to a $46 \%, 22 \%$, and $100 \%$ increase in shoot length (Fig. 1a), and 19\%, $0 \%$, and $33 \%$ increase in emerging plants (Fig. 1b) by copper, lead, and zinc, respectively. This could be counted as an essential element in promoting plant growth. In one study, $5 \mathrm{ppm}$ of $\mathrm{Cr}^{+6}, \mathrm{Cu}^{+2}, \mathrm{Ni}^{+2}$, and $\mathrm{Zn}^{+2}$ increased the shoot size by $13.0 \%, 59.0 \%, 35.0 \%$, and $6.6 \%$, respectively [1], and 

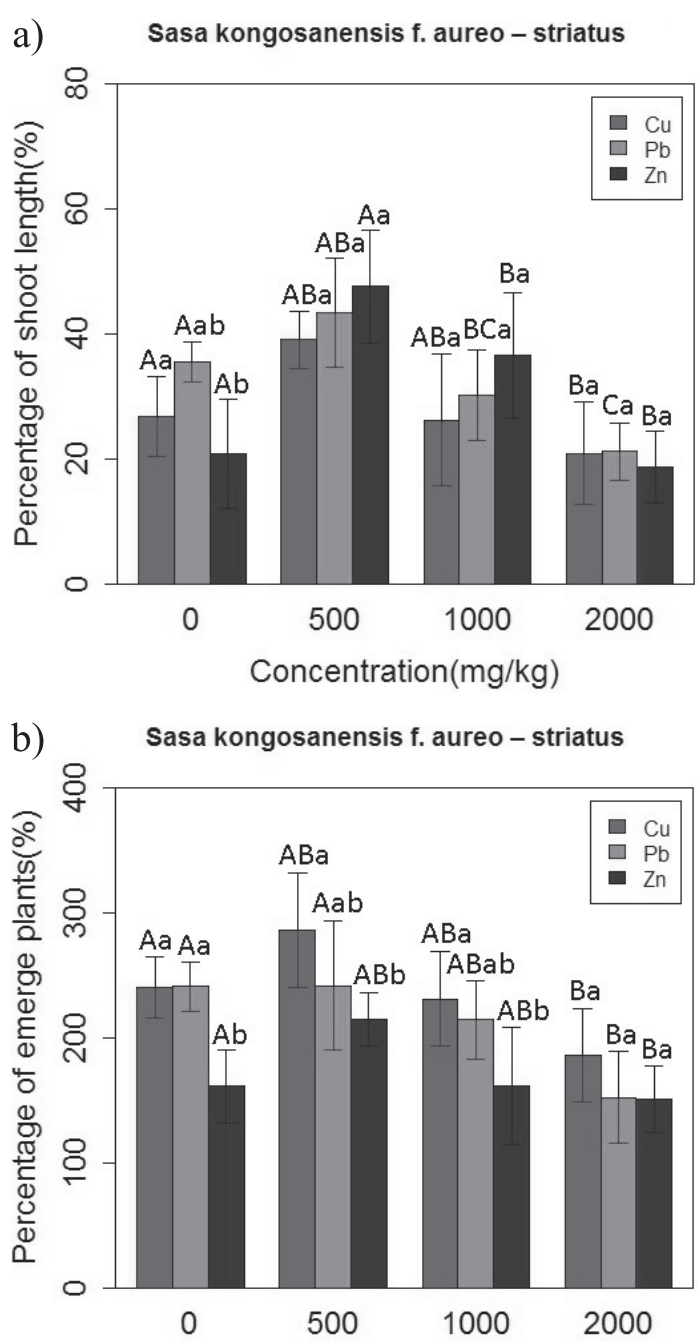

Fig. 1. Effects of HMs on plant growth indices: percentage of shoot length a) and percentage of emerged plants b). The capital letters are the demonstration of statistical significance between different concentrations of HM and the small letters are the demonstration of statistical significance between different HMs in each concentration.

also showed an effect in low concentrations of $\mathrm{Cu}$ in Vicia faba [31].

Overall, in the present study plant growth (i.e., percentage of shoot length and percentage of emerging plants) is shown to have an arc-shaped response to an excess of HMs so that at low concentrations $(500 \mathrm{mg} / \mathrm{kg})$, plant growth indexes increased, and then at high concentrations $(1,000 \mathrm{mg} / \mathrm{kg}$ and $2,000 \mathrm{mg} / \mathrm{kg})$ plant growth indexes decreased. Among our HMs, Zn was seen to have a high impact of plant growth in low concentrations while $\mathrm{Pb}$ was shown to have a high negative effect on plant growth.

\section{Conclusions}

Tolerance thresholds to abiotic stress are different in plants and determined by genetics and district environment where the plant grows. The rapid growth of
HMs by anthropogenic activities has a negative impact on plant cycles and activates defensive mechanisms, while the logical values of these HMs are mainly used as nutrients in plants. In the present study, the effects of different concentrations of $\mathrm{HMs}(\mathrm{Cu}, \mathrm{Pb}$, and $\mathrm{Zn})$ on Sasa kongosanensis $f$. aureo - striatus indicated that the low levels of HMs $(500 \mathrm{mg} / \mathrm{kg})$ have a positive impact on plant metabolism and can help plant growth, while an excess of HMs $(1,000-2,000 \mathrm{mg} / \mathrm{kg})$ mainly decrease growth and put a tolerance threshold in our Sasa kongosanensis $f$. aureo - striatus bamboo species.

Overall, our results showed that the effectiveness of antioxidant mechanisms corresponds to heavy metal stress so that at low concentrations of heavy metals, the enhancement of antioxidant enzyme activity improved the growth and development of plants, while with the excess of heavy metals $(1,000$ and 2,000), antioxidant enzyme activity decreased. This could enhance lipid production, reduce photosynthetic properties, and, consequently, reduce the plant growth indexes.

Also in our study, $\mathrm{Pb}$ was revealed the have the lowest antioxidant activity, which led to most membrane damage and, consequently, showed the lowest plant growth over the three HMs tested in our study, while Zn showed the most increasing growth plant in low concentrations.

\section{Acknowledgements}

Our work was supported by the $12^{\text {th }}$ Five-Year Forestry Science and Technology Support Program of China (No. 2012BAD23B05) and by the Priority Academic Program Development of the Jiangsu Education Administration.

\section{References}

1. AYDINALP C., MARINOVA S. The effects of heavy metals on seed germination and plant growth on alfalfa plant (Medicago Sativa).Bulg. J. Agric .15 (4), 347, 2009.

2. VIDAKOVIC-CIFREK Z., TKALEC M., SIKIC S., TOLIC S., LEPEDUS H., PEVALEK-KOZLINA B. Growth and photosynthetic responses of Lemna minor L. exposed to cadmium in combination with zinc or copper .Arh Hig Rada Toksikol. 66 (2), 141, 2015.

3. LU K., YANG X., SHEN J., ROBINSON B., HUANG H., LIU D., BOLANE N., PEIB J., WANG H. Effect of bamboo and rice straw bio chars on the bioavailability of $\mathrm{Cd}, \mathrm{Cu}$, $\mathrm{Pb}$ and $\mathrm{Zn}$ to Sedum plumbizincicola. Agr. Ecosyst Environ. 191, 124, 2014.

4. HALL J.L. Cellular mechanisms for heavy metal detoxification and tolerance. J. Exp. Bot. 53, 1, 2002.

5. SRIVASTAVA S., MISHRA S., TRIPATHI R.D., DWIVEDI S., GUPTA D.K. Copper-induced oxidative stress and responses of antioxidants and phytochelatins in Hydrilla verticillata (L.f.) Royle. Aquat Toxicol. 80 (4), 405, 2006.

6. LUKATKIN A., EGOROVA I., MICHAILOVA I., MALEC P., STRZALKA K. Effect of copper on pro- and antoxidative reactions in radish (Raphanus sativus L.) in vitro and in vivo. J Trace Elem Med Biol. 28 (1), 80, 2014. 
7. DAI H.P., SHAN C.J., ZHAO H., LI J.C., JIA G.L., JIANG H., WU S.Q., WANG Q. The difference in antioxidant capacity of four alfalfa cultivars in response to $\mathrm{Zn}$. Ecotoxicol Environ Saf. 114, 312, 2015.

8. KABALA K., JANICKA-RUSSAK M., KLOBUS G. Different responses of tonoplast proton pumps in cucumber roots to cadmium and copper. J Plant Physiol. 167, (16), 1328, 2010.

9. SUN B.Y., KAN S.H., ZHANG Y.Z., DENG S.H., WU J., YUAN H., QI H., YANG G., LI L., ZHANG X.H., XIAO H., WANG Y.J., PENG H., Li Y.W. certain antioxidant enzymes and lipid peroxidation of radish (Raphanus sativus L.) as early warning biomarkers of soil copper exposure. J Hazard Mater. 183 (1-3), 833, 2010.

10. KARIMI P., KHAVARI-NEJAD R.A., NIKNAM V., GHAHREMANINEJAD F., NAJAFI F. The effects of excess copper on antioxidative Enzymes, Lipid Peroxidation, Proline, Chlorophyll, and Concentration of $\mathrm{Mn}, \mathrm{Fe}$, and $\mathrm{Cu}$ in Astragalus neo-mobayenii .The Scientific World Journal. 6, 615670, 2012.

11. CVJETKO P., TOLIC S., SIKIC S., BALEN B., TKALEC M., VIDAKOVIC-CIFREK Z., PAVLICA M. Effect OF Copper on the toxicity and genotoxicity of Cadmium in DUCKWEED (Lemna Minor L.). Arh Hig Rada Toksikol. 61 (3), 287, 2010.

12. OKAMURA H., TANAKA Y., KONISHI M., KASHIWAGI H. Illustrated Horticultural Bamboo species in japan. HAATO limited publishers.170-36 shinzaike w akayama. 640, 1991 [In Japanese].

13. NI Q., XU G., GAO Q., YANG D., ZHANG Y. Evaluation of reactive oxygen species scavenging activities and DNA damage prevention effect of Pleioblastus kongosanensis $f$. aureostriatus leaf extract by chemiluminescence assay. J Photochem Photobiol B. 128, 115, 2013.

14. ZHANG X Z. The measurement and mechanism of lipid peroxidation and SOD, POD and CAT activities in biological system. In: Zhang XZ (ed) Research Methodology of Crop Physiology .Beijing Agriculture Press. 208, 1992.

15. AEBI H. Catalase in vitro .Methods in Enzymology. 105, 121, 1984.

16. DUAN B., LU Y., YIN C., JUNTTILA O., LI C. Physiological response to drought and shade in two contrasting picea asperata population. Physiol Plant. 124, 476, 2005.

17. BRADFORD M.M. A rapid and sensitive method for the quantification of microgram quantities of protein utilizing the principle of protein-dye binding. Analytical Biochemistry. 72, 248, 1976.

18. BAI X.Y., DONG Y. J., WANG Q.H., XU L.L., KONG J., LIU S. Effects of lead and nitric oxide on photosynthesis, antioxidative ability, and mineral element content of perennial ryegrass .Biologia Plantarum. 59 (1), 163, 2015.

19. TERZI H., YILDIZ M. Interactive effects of sulfur and chromium on antioxidative defence systems and BnMP1 gene expression in canola (Brassica napus L.) cultivars differing in $\mathrm{Cr}$ (VI) tolerance.Ecotoxicology. 24, 1171, 2015.

20. KANG C., KUBA T., HAO A., ISERI Y., Antioxidant Responses of Vallisneria asiatica to Eutrophic Sediments in Lake Taihu, China. Bull Environ Contam Toxicol. 95, 194, 2015.

21. WANG Y.J., DONG Y.X., WANG J., CUI X. M. Alleviating effects of exogenous $\mathrm{NO}$ on tomato seedlings under combined $\mathrm{Cu}$ and $\mathrm{Cd}$ stress .Environ Sci Pollut Res Int. 23 (5), 4826, 2016.

22. BAH A.M., DAI H., ZHAO J., SUN H., CAO F., ZHANG G., WU F. Effects of Cadmium, Chromium and Lead on Growth, Metal Uptake and Antioxidative Capacity in Typha angustifolia, Biol Trace Elem Res. 142 (1), 77, 2011.

23. ZAYNEB C., BASSEM K., ZEINEB K., GRUBB C.D., NOUREDDINE D., HAFEDH M., AMINE Physiological responses of fenugreek seedlings and plants treated with cadmium .Environ Sci Pollut Res Int. 22, 10679, 2015.

24. DAZY M., MASFARAUD J.F., FERARD J.F. Induction of oxidative stress biomarkers associated with heavy metal stress in Fontinalis antipyretica Hedw .Chemosphere. 75, 297, 2009.

25. JABEEN N., ABBAS Z., IQBAL M., RIZWAN M., JABBAR A., FARID M., ALI S., IBRAHIM M., ABBAS F. Glycinebetaine mediates chromium tolerance in mung bean through lowering of $\mathrm{Cr}$ uptake and improved antioxidant system. Archives of Agronomy and Soil Science. 62 (5), 648, 2016.

26. HE J., JI Z.X., WANG Q.Z., LIU C.F., ZHOU Y.B. Effect of $\mathrm{Cu}$ and $\mathrm{Pb}$ pollution on the growth and antioxidant enzyme activity of Suaeda heteroptera.Ecological Engineering. 87, $102,2016$.

27. MALAR S., VIKRAM S.S., FAVAS P.J.C., PERUMAL V. Lead heavy metal toxicity induced changes on growth and antioxidative enzymes level in water hyacinths [Eichhornia crassipes (Mart.)]. Botanical Studies. 55, 54, 2014.

28. MALAR S., MANIKANDAN R., FAVAS P.J., VIKRAM SAHI S., VENKATACHALAM P. Effect of lead on phytotoxicity, growth, biochemical alterations and its role on genomic template stability in Sesbania grandiflora: a potential plant for phytoremediation. Ecotoxicol Environ Saf. 108, 249, 2014.

29. LIU J.J.,WEI J., LI J.H. Effects of copper on leaf membrane structure and root activity of maize seedling .Botanical Studies. 55, 47, 2014.

30. ZAHEER I.E., ALI S., RIZWAN M., FARID M., SHAKOOR M.B., GILL R.A., NAJEEB U., IQBAL N., AHMAD R. Citric acid assisted phytoremediation of copper by Brassicanapus L . Ecotoxicol Environ Saf. 120, 310, 2015.

31. FATNASSI I.C., CHIBOUB M., SAADANI O., JEBARA M., JEBARA S.H. Impact of dual inoculation with Rhizobium and PGPR on growth and antioxidant status of Vicia faba L. under copper stress .C R Biol. 338 (4), 241, 2015.

32. GONZALEZ C.I., MAINE M.A., CAZENAVE J., HADAD H.R., BENAVIDES M.P. Ni accumulation and its effects on physiological and biochemical parameters of Eichhornia crassipes. Environ. Exp. Bot. 117, 20, 2015.

33. LOMAGLIO T., ROCCO M., TRUPIANO D., DE ZIOA E., GROSSO A., MARRA M., DELFINE S., CHIATANTE D., MORABITO D., SCIPPA G.S. Effect of short-term cadmium stress on Populus nigra L. detached leaves. J Plant Physiol. 182, 40, 2015.

34. CHAI M., SHI F., LI R., QIU G., LIU F., LIU L. Growth and physiological responses to copper stress in a halophyte Spartina alterniflora (Poaceae). Acta Physiol Plant. 36, 745, 2014.

35. HASSAN M., MANSOOR S. Oxidative stress and antioxidant defense mechanism in mung bean seedlings after lead and cadmium treatments. Turk J Agric For. 38, 55, 2014.

36. LIU D., LI T.Q., YANG X.E., ISLAM E., JIN X.F., MAHMOOD Q. Effect of $\mathrm{Pb}$ on leaf antioxidant enzyme activities and ultrastructure of the two ecotypes of Sedum alfredii Hance. Russ J Plant Physiol. 55, 68, 2008.

37. BELKHADI A., HEDIJI H., ABBES Z., NOUAIRI I., BARHOUMI Z., ZARROUK M., CHAIBI W., DJEBALI W. Effects of exogenous salicylic acid pre-treatment on cadmium toxicity and leaf lipid content in Linum usitatissimum L. Ecotoxicol Environ Saf. 73, 1004, 2010. 
38. BAZIHIZINA N., COLZI I., GIOMI E., MANCUSO S., GONNELLI C. Photosynthesizing on metal excess: Copper differently induced changes in various photosynthetic parameters in copper tolerant and sensitive Silene paradoxa L. populations. Plant Sci. 232, 67, 2015.

39. CVJETKO P., TOLIC S., SIKIC S., BALEN B., TKALEC M., VIDAKOVIC-CIFREK Z., PAVLICA M. Effect of copper on the toxicity and genotoxicity of cadmium in duck weed (Lemna minor L.). Arh Hig Rada Toksikol. 61, 287, 2010.

40. CHEN Y.P., LIU Q., YUE X.Z., MENG Z.W., LIANG J. Ultrasonic vibration seeds showed improved resistance to cadmium and lead in wheat seedling. Environ Sci Pollut Res. 20, 4807, 2013.

41. QIAO X., SHI G., CHEN L., TIAN X., XU X. Lead-induced oxidative damage in steriled seedlings of Nymphoides peltatum. Environ Sci Pollut Res. 20, 5047, 2013.

42. AGGARWAL A., SHARMA I., MUNJAL A.K., BAUNTHIYAL M., SHARMA V. Metal Toxicity and Photosynthesis; Department of bioscience and biotechnology, Banasthali University; 304022, INDIA, 2012.

43. CHEN Y.E., CUI J.M., YANG J.C., ZHANG Z.W., YUAN M., SONG C., YANG H., LIU HM., WANG C.Q., ZHANG H.Y., ZENG X.Y., YUAN S. Bio monitoring heavy metal contaminations by moss visible parameters. J Hazard Mater. 296, 201, 2015.

44. DEZHBAN A., SHIRVANI A., ATTAROD P., DELSHAD M., MATINIZADE M., KHOSHNEVIS M, Cadmium and lead effects on chlorophyll fluorescence, chlorophyll pigments and proline of Robinia pseudoacacia, J. For. Res. 26 (2), 323, 2015.

45. DONG J., WU F.B., ZHANG G.P., Effect of cadmium on growth and photosynthesis of tomato seedlings .J Zhejiang Univ Sci B. 6 (10), 974, 2005.

46. BROWN D.H., WELLS J.M. Physiological Effects of Heavy Metals on the Moss Rhytidiadelphus squarrosus, Ann Bot. 66 (6), 641, 1990.

47. BABU N.G., SARMA P.A., ATTITALLA I.H., MURTHY S.D.S. Effect of Selected Heavy Metal Ions on the Photosynthetic Electron Transport and Energy Transfer in the Thylakoid Membrane of the Cyanobacterium, Spirulina platensis .Academic Journal of Plant Sciences. 3 (1), 46, 2010.
48. VENTRELLAA., CATUCCI L., PILETSKA E., PILETSKY S., AGOSTIANO A. Interactions between heavy metals and photosynthetic materials studied by optical techniques Bioelectrochemistry. 77 (1), 19, 2009.

49. KANWAL U., ALI S., SHAKOOR M.B., FARID M., HUSSAIN S., YASMEEN T., ADREES M., BHARWANA S.A., ABBAS F., EDTA ameliorates phytoextraction of lead and plant growth by reducing morphological and biochemical injuries in Brassica napus L. under lead stress. Environ Sci Pollut Res Int. 21, 9899, 2014.

50. MSLRCKA A., PIECHALAK A., ZIELINSKA B., KUTROWSKA A., TOMASZEWSKA B. Response of the pea roots defense systems to the two element combinations of metals $(\mathrm{Cu}, \mathrm{Zn}, \mathrm{Cd}, \mathrm{Pb})$. Acta Biochim Pol. 61 (1), 23, 2014.

51. XU Z., ZHOU Q., LIU W. Joint effects of cadmium and lead on seedlings of four Chinese cabbage cultivars in north eastern China. J Environ Sci. 21 (11), 1598, 2009 [In China].

52. CHAI M., SHI F., LI R., QIU G., LIU F., LIU L. Growth and physiological responses to copper stress in a halophyte Spartina alterniflora (Poaceae). Acta Physiol. Plant. 36, 745, 2014.

53. JAIN R., SRIVASTAVA S., SOLOMON S., SHRIVASTAVA A.K., CHANDRA A. Impact of excess zinc on growth parameters, cell division, nutrient accumulation, photosynthetic pigments and oxidative stress of sugarcane (Saccharum spp.). Acta Physiol Plant. 32, 979, 2010.

54. MICHAEL P.I., KRISHNASWAMY M.The effect of zinc stress combined with high irradiance stress on membrane damage and antioxidative response in bean seedlings. Environ. Exp. Bot. 74, 171, 2011.

55. ALI S., CHAUDHARY A., RIZWAN M., ANWAR H.T., ADREES M., FARID M., IRSHAD M.K., HAYAT T., ANJUM S.A., Alleviation of chromium toxicity by glycinebetaine is related to elevated antioxidant enzymes and suppressed chromium uptake and oxidative stress in wheat (Triticum aestivum L.). Environ Sci Pollut Res Int. 22, 10669, 2015.

56. AFSHAN S., ALI S., BHARWANA S.A., RIZWAN M., FARID M., ABBAS F., IBRAHIM M., MEHMOOD M.A., ABBASI G.H. Citric acid enhances the phytoextraction of chromium, plant growth, and photosynthesis by alleviating the oxidative damages in Brassica napus L, Environ Sci Pollut Res Int. 22 (15), 11679, 2015. 